\title{
Bone metabolism in patients with mucopolysaccharidosis type II
}

\section{Metabolizm kostny u pacjentów z mukopolisacharydoza typu II}

\author{
Zbigniew Żuber ${ }^{1}$, Agnieszka Jurecka ${ }^{2,3}$, Anna Król-Zdechlikiewicz ${ }^{1}$, \\ Agnieszka Różdżyńska-Świątkowska ${ }^{4}$, Anna Tylki-Szymańska ${ }^{5}$ \\ ${ }^{1}$ Department of Pediatrics, St. Louis Regional Children's Hospital, Cracow \\ ${ }^{2}$ Department of Genetics, University of Gdańsk, Gdańsk \\ ${ }^{3}$ Department of Medical Genetics, The Children's Memorial Health Institute, Warsaw \\ ${ }^{4}$ Anthropology Laboratory, The Children's Memorial Health Institute, Warsaw \\ ${ }^{5}$ Department of Pediatrics, Metabolic Diseases and Nutrition, The Children's Memorial Health Institute, Warsaw
}

Key words: mucopolysaccharidosis, bone mineral density, osteoporosis, vitamin D.

Słowa kluczowe: mukopolisacharydoza, gęstość mineralna kości, osteoporoza, witamina D.

\begin{abstract}
Summary
Objectives: To assess different parameters of bone metabolism in patients with mucopolysaccharidosis type II (MPS II) to better comprehend the mechanisms responsible for their skeletal pathology. Material and methods: In MPS type II patients ( $n=7$, age 4-28 years, mean 11.6, median 7) bone metabolism was assessed using the following: a) parameters of calcium-phosphate metabolism (serum level of calcium, phosphorus, alkaline phosphatase (ALP), parathormone (PTH), and vitamin 25(OH)D), b) parameters of bone formation (osteocalcin) and resorption (B-crossLaps), c) bone mineral density (BMD) of the lumbar spine assessed by dual-energy $X$-ray absorptiometry (DXA), and d) radiographs of the skeletal system. Results: All patients were normocalcemic, but the majority of them had abnormal serum levels of other parameters of calcium-phosphate metabolism such as: hypophosphatemia (4/7), decreased ALP (2/7), increased PTH (4/7), and vitamin 25(OH)D deficiency (6/7), which in 3 patients was associated with secondary hyperparathyroidism. Five patients presented increased levels of osteocalcin in the serum, and all the patients had high levels of $\beta$-CTx. Two adult patients had osteoporosis (T-scores -3.9 and -5.7 ), while in 3 pediatric patients the Z-score was within the normal range. Radiographs of bones revealed signs of dysostosis multiplex typical for MPS disease in all patients, and in adult patients they corresponded to BMD. Conclusions: 1. MPS II patients have disturbed serum parameters of bone health and therefore may be at a higher risk for osteoporosis or osteomalacia. 2. Supplementation with vitamin D may be required in MPS patients.
\end{abstract}

\section{Streszczenie}

Cel pracy: Ocena metabolizmu kostnego u chorych na mukopolisacharydozę typu II (MPS II) w celu lepszego zrozumienia mechanizmów odpowiedzialnych za patologię kostną w MPS.

Materiat i metody: Analizie poddano wybrane parametry metabolizmu kostnego pacjentów chorujących na MPS $\|(n=7$, wiek 4-28 lat, średnia 11,6, mediana 7). Metabolizm kostny oceniano na podstawie: a) stężenia wapnia, fosforu, fosfatazy alkalicznej, parathormonu, witaminy 25(OH)D, b) parametrów tworzenia kości (osteokalcyna) i resorpcji (B-CrossLaps), c) gęstości mineralnej kości (BMD) kręgosłupa lędźwiowego o podwójnej energii promieniowania rentgenowskiego (DXA), d) zdjęć rentgenowskich układu kostno-stawowego.

Wyniki: Wszyscy pacjenci mieli prawidłowe stężenie wapnia w surowicy, $u$ większości chorych odnotowano odchylenia od normy w zakresie innych oznaczanych parametrów metabolizmu wapnia, w postaci: hipofosfatemii (4/7), zmniejszenia stężenia fosfatazy alkalicznej (2/7), zwiększenia stężenia parathormonu (4/7) oraz zmniejszenia stężenia witaminy D (6/7), które u 3 pacjentów było związane z wtórną nadczynnością przytarczyc. U 5 chorych stwierdzono zwiększone stężenia osteokalcyny, u wszystkich pacjentów odnotowano duże stężenia $\beta$-CTx. $\cup 2$ dorosłych pacjentów wyniki DXA wskazywały na osteoporozę (T-score $-3,9$ i $-5,7$ ), natomiast u 3 pacjentów w wieku rozwojowym wyniki badań DXA (Z-score) były $w$ granicach normy. Badania rentgenowskie układu kostnego wykazały zmiany charakterystyczne dla osób chorujących na mukopolisacharydozy typu dysostosis multiplex u wszystkich badanych osób - zarówno dorostych, jak i dzieci.

Wnioski: 1. U osób chorujących na MPS II odnotowywane są zaburzenia parametrów metabolizmu kostnego, chorzy ci mogą być bardziej narażeni na osteoporozę lub osteomalację. 2. U wszystkich chorych na MPS może być konieczna suplementacja witaminą D.

\section{Address for correspondence}

Agnieszka Jurecka, MD, PhD, Department of Genetics, University of Gdańsk, Wita Stwosza 59, 80-308 Gdańsk,

e-mail: ajurecka@gmail.com

Submitted: 25.07 .2014 


\section{Introduction}

Mucopolysaccharidoses (MPSs) are rare inborn errors of metabolism owing to enzymatic deficiencies in the degradation of glycosaminoglycans (GAGs). GAGs accumulate in the lysosomes of the affected individuals, leading to different symptoms, which are responsible for a complex clinical picture. Mucopolysaccharidosis type II (MPS II, Hunter syndrome, OMIM\# 309900) is caused by a deficiency of the enzyme iduronate-2-sulfatase (I2S; EC 3.1.6.13), which is responsible for breaking down heparan and dermatan sulfate (HS and DS) within the cells [1]. It is a rare and life-limiting $X$-linked recessive disorder that affects approximately 1 in 77,000 newborn boys [2, 3]. The vast majority of patients are male, but occasionally females may also be affected due to X-chromosome inactivation of skewed expression $[4,5]$.

Although bone growth and mineralization are affected by GAG accumulation in the tissues of MPS animal models [6-8], there is very little data available on the assessment of bone metabolism in patients with MPSs [9-11]. The severity of bone disease varies according to the type of MPS, however most of the skeletal anomalies in MPS patients are likely to originate from aberrant cartilage and bone development, especially endochondral ossification [12]. The main causes of osteopenia in MPS patients are probably abnormal bone remodeling (osteoblast/osteoclast dysfunction) and abnormalities in the growth plate, exacerbated by immobility in an advanced stage of the disease. As a clinical hallmark, the term dysostosis multiplex, refers to the radiographic bone changes manifesting through short stature and progressive skeletal deformation, which are seen in some storage disorders and almost all different types of MPSs with the exception of MPS III [1]. Growth abnormalities are commonly observed in MPS patients and are likely secondary to a combination of structural, metabolic and endocrine factors.

Currently, a clinically available treatment option for MPS II is enzyme replacement therapy (ERT) using idursulfase (recombinant human 2IS, Elaprase, Shire Human Genetic Therapies, Inc., Lexington, MA, USA). However, this treatment has proven relatively ineffective at correcting bone disease [13-17].

The aim of this study was to analyze different parameters of bone metabolism in MPS II patients to better comprehend the mechanisms responsible for their skeletal pathology.

\section{Material and methods \\ Study design}

The study objective was to analyze different parameters of bone metabolism in patients with MPS II. All patients were enrolled at the Department of Pediatrics, St. Louis Regional Children's Hospital, Cracow, Poland.

\section{Patients}

All patients participating in the study had a diagnosis of MPS II confirmed by the biochemical determination of iduronate-2-sulfatase deficiency in leukocytes and by molecular analysis. Patients' characteristics are shown in Table I.

\section{Assessments}

The following parameters were analyzed:

1. Parameters of calcium-phosphate metabolism (serum levels of: calcium, phosphorus, alkaline phosphatase (ALP), parathormone (PTH), 25(OH)D).

Total serum 25(OH)D, the metabolic precursor of calcitriol, is considered the best indicator of body stores and vitamin $\mathrm{D}$ axis activity. Vitamin $\mathrm{D}$ deficiency and insufficiency were defined as $25(\mathrm{OH}) \mathrm{D}$ concentration $<50 \mathrm{nmol} / \mathrm{l}(20 \mathrm{ng} / \mathrm{ml})$ and between 50 and $75 \mathrm{nmol} / \mathrm{l}$ $[18,19]$.

2. Parameters of bone formation (osteocalcin) and resorption (B-crossLaps) in serum.

3. Bone mineral density (BMD) of the lumbar spine using dual energy X-ray absorptiometry (DXA). BMD of the lumbar spine (L1-L4) was assessed by DXA using the Hologic QDR DELPHI W (USA). For the pediatric patients, the BMD results were converted to age- and gender-specific Z-scores based on the WHO normative reference data for BMD [20]. Due to the considerable height deficits for MPS patients, BMD Z-scores were then adjusted for height-for-age Z-score (HAZ) according to the method of Zemel et al. [21], which provides an adjustment for growth deficits in BMD by DXA. For the 2 patients above age 19 , the BMD results were converted to gender-specific T-scores based on WHO normative reference data for BMD [20]. The World Health Organization (WHO) defines osteoporosis in adults as a lumbar spine DXA T-score $<-2.5$.

4. Radiographs of osteoarticular system (hands, thoraco-lumbar spine, and long bones).

\section{Ethical consideration}

The protocol was approved by the human-subjects institutional review board at St. Louis Hospital. Written informed consent had to be provided by the parents or legal guardians.

\section{Results}

Parameters of calcium-phosphate metabolism (serum levels of calcium, phosphorus, alkaline phosphatase 
Table I. Patient characteristics (demographic, molecular characteristics and clinical phenotypes)

\begin{tabular}{|c|c|c|c|c|c|}
\hline $\begin{array}{l}\text { Patient } \\
\text { No. }\end{array}$ & $\begin{array}{c}\text { Age at } \\
\text { diagnosis } \\
\text { (years) }\end{array}$ & $\begin{array}{l}\text { Body height }(\mathrm{cm}) / \\
\text { percentile }\end{array}$ & $\begin{array}{l}\text { Current age } \\
\text { (years) }\end{array}$ & Mutations & Phenotype \\
\hline 1 & 6 & $150\left(<3^{\text {rd }}\right)$ & 29.5 & nd & neurological \\
\hline 2 & 3 & $125\left(<3^{\text {rd }}\right)$ & 22.5 & nd & neurological \\
\hline 3 & 6 & $122\left(<3^{\text {rd }}\right)$ & 9 & deletion of IDS gene & neurological \\
\hline 4 & 6 & $136\left(<3^{\text {rd }}\right)$ & 11.5 & $c .257 C>T$ & neurological \\
\hline 5 & 4 & $120.2\left(<3^{\text {rd }}\right)$ & 9 & c.1001 A>C & neurological \\
\hline 6 & 3.5 & $117.9\left(50^{\text {th }}\right)$ & 4.5 & $c .998 C>T$ & neurological \\
\hline 7 & 4 & $121.5\left(50^{\text {th }}\right)$ & 5.5 & intragenic inversion & neurological \\
\hline
\end{tabular}

nd-not done

(ALP), parathormone (PTH), 25(OH)D) are presented in Table II. It was found that all patients were normocalcemic, while 4/7 presented with hypophosphatemia.

In 5 patients levels of alkaline phosphatase were within the normal range, while in 2 they were below the normal level. Four patients had an increased level of PTH.

Six patients had decreased levels of vitamin $25(\mathrm{OH}) \mathrm{D}$, in 5 of them it was significant $(<10 \mathrm{ng} / \mathrm{ml})$. In the youngest patient, vitamin 25(OH)D level was within the lower normal range. In 3 patients, decreased level of vitamin 25(OH)D was associated with increased serum level of PTH (secondary hyperparathyroidism).

Assessment of bone turnover (osteocalcin) and B-Ctx (Table II) demonstrated that 5 patients had increased levels of osteocalcin, and all patients had high levels of beta-CTx.
Bone mineral density (BMD) of the lumbar spine assessed by DXA of the lumbar spine was performed in 5 out of 7 patients, including 2 patients over 18 years old. Two patients were not assessed - in one case due to the young age of the patient (under 5 years), while in the second case - the patient refused.

The study revealed that 2 adult patients had osteoporosis (T-scores -3.9 and -5.7 ) and the fracture risk was assessed as high, however in 3 pediatric patients the Z-score was within the normal range.

Radiographs in 2 adult patients corresponded to BMD. In these patients, significant loss of bone mass was observed in long bones, tarsal bones, metaphyses of forearms, wrist bones, and vertebrae. Radiographs were also assessed to confirm dysostosis multiplex and other radiological skeletal manifestations of MPS II and included radiographs of hands which showed: hypoplas-

Table II. Parameters of calcium-phosphate metabolism as well as bone formation and resorption in MPS II patients

\begin{tabular}{|c|c|c|c|c|c|c|c|}
\hline Patient & $\begin{array}{l}\text { Calcium } \\
(\mathrm{mmol} / \mathrm{l})\end{array}$ & $\begin{array}{l}\text { Phosphorus } \\
(\mathrm{mmol} / \mathrm{l})\end{array}$ & $\begin{array}{l}\text { ALP } \\
(\mathrm{U} / \mathrm{L})\end{array}$ & $\begin{array}{l}\text { PTH } \\
(\mathrm{pg} / \mathrm{ml})\end{array}$ & $\begin{array}{c}25(\mathrm{OH}) \mathrm{D}_{3} \\
(\mathrm{ng} / \mathrm{ml})\end{array}$ & $\begin{array}{l}\text { Osteocalcin } \\
(\mathrm{ng} / \mathrm{ml})\end{array}$ & $\begin{array}{c}\text { CrossLaps } \\
(\mathrm{pg} / \mathrm{ml})\end{array}$ \\
\hline 1 & $\begin{array}{c}2.25 \\
(2.10-2.55)\end{array}$ & $\begin{array}{c}1.21 \\
(0.87-1.45)\end{array}$ & $\begin{array}{c}119 \\
(55-212)\end{array}$ & $\begin{array}{c}41.05 \\
(15-65)\end{array}$ & $\begin{array}{l}22.14 \downarrow \\
(30-80)\end{array}$ & $\begin{array}{l}57.02 \\
(0-70)\end{array}$ & 673.00 \\
\hline 2 & $\begin{array}{c}2.17 \\
(2.10-2.55)\end{array}$ & $\begin{array}{c}1.34 \\
(0.87-1.45)\end{array}$ & $\begin{array}{c}146 \\
(55-212)\end{array}$ & $\begin{array}{c}35.80 \\
(15-65)\end{array}$ & $\begin{array}{l}8.58 \downarrow \\
(30-80)\end{array}$ & $\begin{array}{c}148.90 \uparrow \\
(0-70)\end{array}$ & 2824.00 \\
\hline 3 & $\begin{array}{c}2.21 \\
(2.20-2.70)\end{array}$ & $\begin{array}{c}1.37 \downarrow \\
(1.45-1.78)\end{array}$ & $\begin{array}{c}136 \downarrow \\
(156-386) \\
\end{array}$ & $\begin{array}{c}77.87 \uparrow \\
(4.60-34.00) \\
\end{array}$ & $\begin{array}{l}<4.00 \downarrow \\
(20-60)\end{array}$ & $\begin{array}{r}74.01 \uparrow \\
(0-70) \\
\end{array}$ & 930.20 \\
\hline 4 & $\begin{array}{c}2.32 \\
(2.20-2.70)\end{array}$ & $\begin{array}{c}1.44 \downarrow \\
(1.45-1.78)\end{array}$ & $\begin{array}{c}212 \\
(122-488) \\
\end{array}$ & $\begin{array}{c}27.64 \\
(2.50-25.00) \\
\end{array}$ & $\begin{array}{l}<4.00 \downarrow \\
(20-60)\end{array}$ & $\begin{array}{l}49.09 \\
(0-70) \\
\end{array}$ & 1106.00 \\
\hline 5 & $\begin{array}{c}2.44 \\
(2.20-2.70)\end{array}$ & $\begin{array}{c}1.36 \downarrow \\
(1.45-1.78)\end{array}$ & $\begin{array}{c}142 \downarrow \\
(156-386)\end{array}$ & $\begin{array}{c}25.67 \\
(4.60-34.00)\end{array}$ & $\begin{array}{c}4.95 \downarrow \\
(20-60)\end{array}$ & $\begin{array}{l}81.23 \uparrow \\
(0-70)\end{array}$ & 876.50 \\
\hline 6 & $\begin{array}{c}2.47 \\
(2.20-2.70)\end{array}$ & $\begin{array}{c}1.68 \\
(1.45-1.78) \\
\end{array}$ & $\begin{array}{c}308 \\
(134-346) \\
\end{array}$ & $\begin{array}{c}31.29 \uparrow \\
(4.40-16.00)\end{array}$ & $\begin{array}{c}29.06 \\
(20-60) \\
\end{array}$ & $\begin{array}{c}115.10 \uparrow \\
(0-70)\end{array}$ & 1746.00 \\
\hline 7 & $\begin{array}{c}2.42 \\
(2.20-2.70)\end{array}$ & $\begin{array}{c}1.40 \downarrow \\
(1.45-1.78)\end{array}$ & $\begin{array}{c}215 \\
(134-346)\end{array}$ & $\begin{array}{c}21.39 \uparrow \\
(4.40-16.00)\end{array}$ & $\begin{array}{l}7.62 \downarrow \\
(20-60)\end{array}$ & $\begin{array}{c}200.10 \uparrow \\
(0-70)\end{array}$ & 2202.00 \\
\hline
\end{tabular}

ALP - alkaline phosphatase; PTH - parathormone; ranges in healthy population are presented in brackets 
tic and irregularly shaped carpal bones, proximal pointed metacarpals, bullet-shaped phalanges, V-shaped hypoplastic distal ulna and radius, osteoporosis, and erosions (Fig. 1; patient 1).

Thoraco-lumbar spine X-ray (Fig. 2a and b; patients 4 and 6) showed malformations of the vertebral bodies (a deficiency in its anterosuperior corner and, as a consequence, an apparent prolongation of the anteroinferior one, resulting on the lateral X-ray in an 'anterior beaking' aspect), flattened and rounded vertebrae, scoliosis, osteoporosis, shortened and thickened clavicles, and paddle-shaped ribs.

Also $X$ rays of long bones were performed (Fig. 3a and $\mathrm{b}$; patients 4 and 1 ) and revealed shortened and curved diaphyses, slightly hypoplastic epiphyses thinned cortically with osteoporosis, diffuse cortical thinning, frayed and flared tibial metaphyses, and hypoplasia of the lateral tibial hemiplate resulting in genu valgum.

\section{Discussion}

Pathogenesis of osteopenia and osteoporosis in MPS II patients is multifactorial.

On one hand, a genetic defect results in aberrant cartilage and bone development and progressive changes in the osteoarticular system. On the other hand, decreased physical activity of the patients, and, sometimes, total immobility (lack of mechanical stimulation and vitamin D insufficiency) lead to disruption of

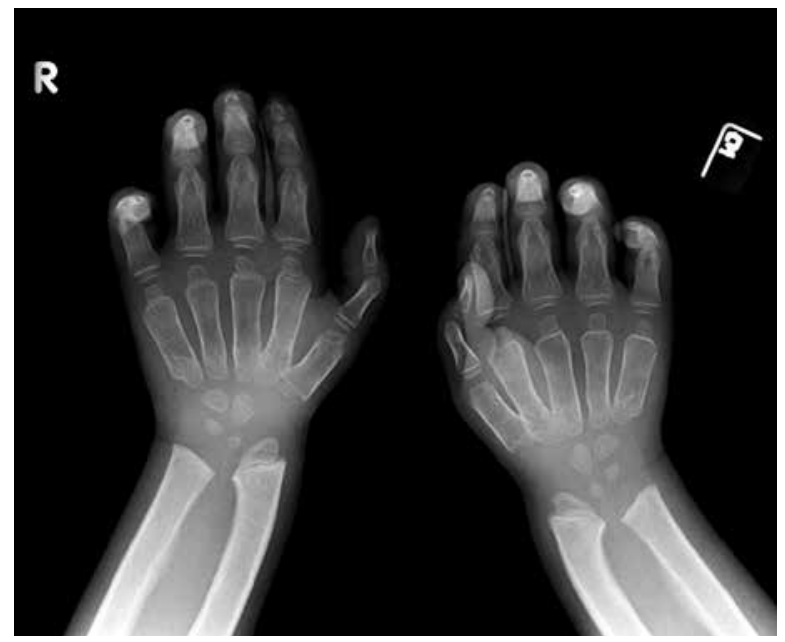

Fig. 1. Manifestations of dysostosis multiplex in the hands. Radiograph showing hypoplastic and irregularly shaped carpal bones, proximal pointed metacarpals, bullet-shaped phalanges, V-shaped hypoplastic distal ulna and radius (patient 1 ).

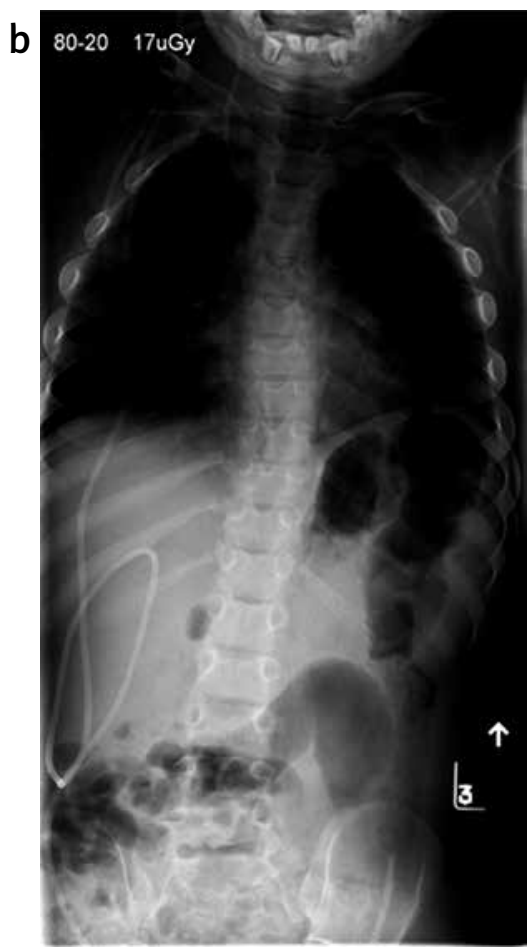

Fig. 2 a,b. Manifestations of dysostosis multiplex in the spine. Radiographs showing (a) malformations of the vertebral bodies (a deficiency in its anterosuperior corner and, as a consequence, apparent prolongation of the anteroinferior one, resulting on the lateral X-ray in an 'anterior beaking' aspect (patient 4); (b) flattened and rounded vertebrae, scoliosis (patient 6). 

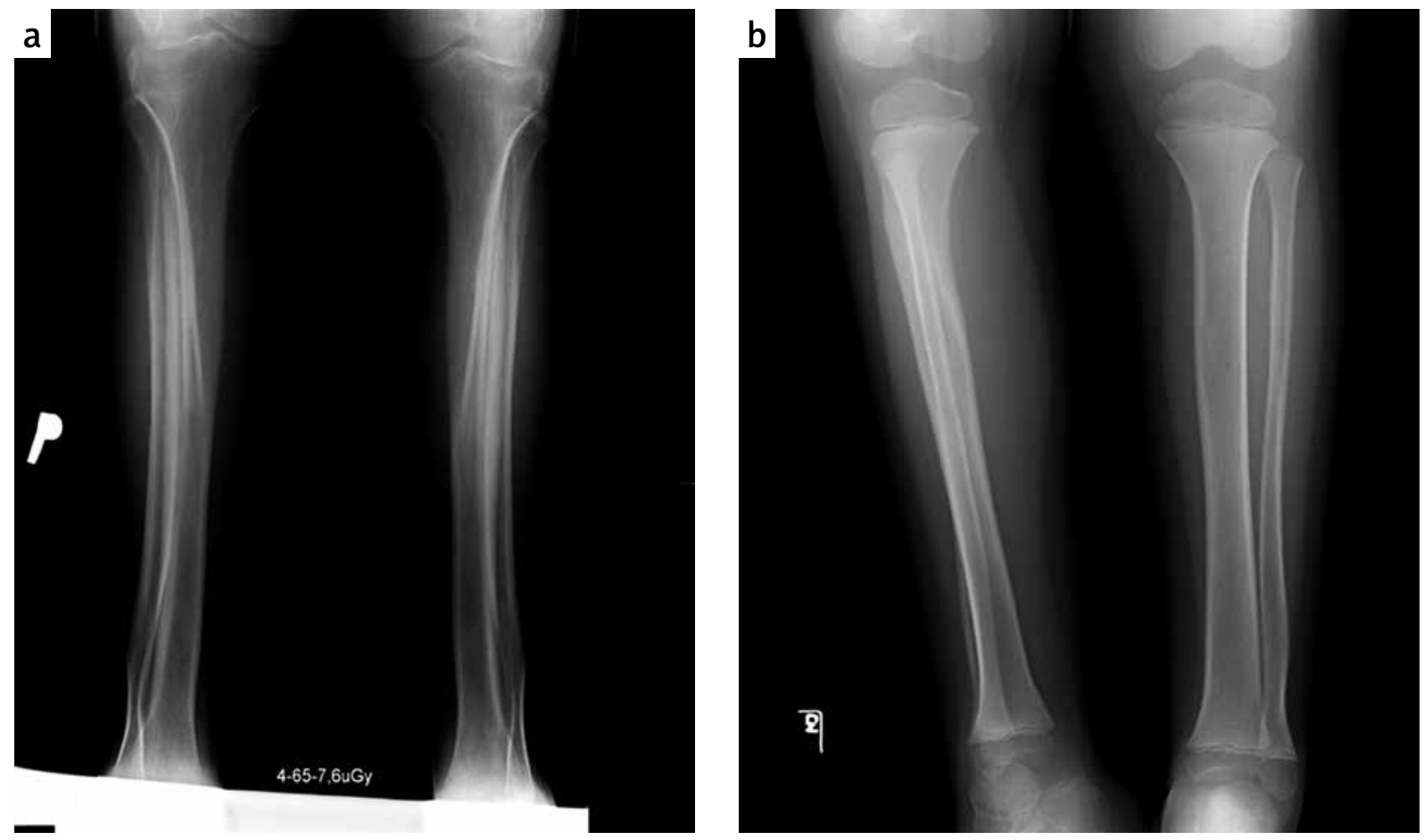

Fig. 3 a,b. Manifestations of dysostosis multiplex in the long bones. Radiographs showing (a) slightly hypoplastic epiphyses thinned cortically with osteoporosis, diffuse cortical thinning, frayed and flared tibial metaphyses (patient 4); (b) shortened and curved diaphyses, slightly hypoplastic epiphyses, thinned, cortically frayed and flared tibial metaphyses, and hypoplasia of the lateral tibial hemiplate (patient 1).

calcium-phosphate homeostasis and bone mass loss. Growth in length relies on the perfectly orchestrated proliferation and differentiation of chondrocytes in the growth plate - a process that is irreversibly disturbed in MPS by the lack of GAG turnover [12]. The main causes of osteopenia in MPS patients are probably abnormal bone remodeling (osteoblast/osteoclast dysfunction) and abnormalities in the growth plate, exacerbated by immobility in an advanced stage of the disease [12]. Secondary cellular responses, involving interaction of GAGs with bone morphogenetic proteins (BMPs) and fibroblast growth factor (FGF), may play a role in all bone and joint problems seen in MPS patients [12]. The psychomotor retardation in MPS II patients might also contribute to osteopenia and osteoporosis. The secondary inducers include immobilization, too little exposure to the sun, poor nutritional status, vitamin D deficiencies and anti-epileptic treatment [12].

To the best of our knowledge, this is the first study describing different parameters of bone metabolism in MPS II patients. We found that MPS II patients were normocalcemic due to the mechanism of calcium homeostasis, which led to the disruption of other parameters of calcium-phosphate metabolism. The majority of our patients had incorrect levels of other parameters of calcium-phosphate metabolism such as: hypophosphatemia, decreased ALP, increased PTH, and vitamin D deficiency with secondary hyperparathyroidism. Only the youngest 4-year-old patient had a vitamin D level within the normal range. Vitamin D insufficiency in patients with MPS II increases with age and is usually significant. Due to low serum levels of vitamin $D_{3}$, all patients started supplementation with vitamin $D_{3}$ (Cholecalciferolum ${ }^{\circledR}$, Polpharma, Poland, dose 3 drops per $500 \mathrm{IU}$ ) as well as calcium (Coral Calcium, dose 1000 IU/24 h) for a period of 12 months.

Vitamin D, a pleiotropic hormone, has been increasingly implicated in the proper functioning of multiple organs, with deficiency states associated with cardiovascular disease, asthma, multiple sclerosis, diabetes, acute lower respiratory infections, and cancer. Vitamin D not only plays a well-established role in calcium homeostasis, but also has been shown to influence cardiac myocytes and endothelial function through cellular receptors [22], as well as modulating white cell proliferation and maturation $[23,24]$. Clinical manifestations of severe vitamin $D$ deficiency such as rickets in children and osteomalacia in adults are rarely noted. The basic abnormalities are delay in skeleton mineralization rate and failure of $1,25(\mathrm{OH})_{2}$-vitamin-D-dependent mechanisms in osteoblasts. Vitamin D plays an important role 
in osteoblast differentiation in vivo, and enhances the in vitro expression of alkaline phosphatase, osteopontin and osteocalcin pivotal genes [25]. In addition, reduced supplies of calcium/phosphorus with secondary hyperparathyroidism may lead to unbalanced bone turnover and osteopenia [11]. Hopefully, early supplementation with vitamin $D$ and calcium will minimize disruption of calcium-phosphorus metabolism and resulting bone loss leading to improved quality of patients' lives. However, subsequent studies are still required to establish whether rapid restoration of vitamin D body stores has an impact on disease course and outcome.

Apart from disrupted calcium-phosphorus metabolism, the majority of our patients had high serum levels of osteocalcin, and all the patients had high levels of $\beta$-CTx leading to high-turnover osteoporosis in the adult patients.

Two adult patients had osteoporosis (T-scores -3.9 and -5.7), while in 3 pediatric patients the Z-score was within the normal range.

Recently, Lin et al. found a high prevalence of osteopenia $(31 \%)$ or osteoporosis $(15 \%)$ by DXA in MPS patients under 19 years of age unselected for skeletal problems [26]. Fung et al. evaluated BMD by DXA in 8 patients with MPS II or VI who were receiving enzyme replacement therapy and found that BMD was within the normal range for most of the patients, particularly after correction for short stature [10]. However, BMD was not measured prior to the initiation of ERT, and thus, it is unclear whether the normal values existed prior to ERT or represented a treatment effect. In our patients, comparison of BMD values shows relevant differences: adult patients had significant degrees of osteoporosis, with low BMD. In contrast pediatric patients showed no densitometric signs of skeletal disease. Differences among these patients were related to the length of the disease process and immobilization in the case of the older patient.

Assessment of BMD of the lumbar spine DXA in MPS patients can be a good tool for monitoring osteoporosis and osteopenia, but only in correlation with bone radiographs, levels of parameters of calcium-phosphorus metabolism and other bone turnover markers. Additionally, the results are corrected for short stature. DXA provides a 2-dimensional image from which 3-dimensional bone density is estimated, which falsely reduces BMD in children with short stature simply because of small bone size [21]. In has to be kept in mind, that bone geometry, which is abnormal in MPS disorders, also influences DXA measurements.

Bone radiographs are not highly sensitive for quantitative bone mass assessment, although incorrect mineralization can be suspected in the spine when trabeculae appear radiologically indistinct or fuzzy [27]. Several MPS types and other lysosomal storage disorders share characteristic skeletal features revealed by $X$-ray radiological examination that are described as dysostosis multiplex. In MPS, dysostosis multiplex generally involves malformations of the skull, thorax, spine, pelvis, long bones and hands. Our patients presented with typical features (Figs. 1-3). Regular imaging of the cervical, thoracic and lumbar spine, the hips and lower extremities is recommended for patients with MPS.

Checks on vitamin D metabolism and DXA represent simple and reproducible means to monitor nutritional supply and assess bone loss in patients with MPS II, although adequate interventions to correct BMD and improve skeletal health in the long term are still needed. Enzyme replacement therapy (ERT) is currently available for MPS II, but it has achieved little improvement of bone disease in humans. Although ERT can be a life-lengthening therapeutic measure, it does not seem to alter the natural history of the skeletal disorder in MPSs and children will still endure the skeletal changes of the disease. Similarly, although hematopoietic stem-cell transplantation (HSCT) leads to some positive changes, it does not greatly reduce the skeletal abnormalities. Another alternative might be growth hormone $(\mathrm{GH})$, which improves osteopenia in pediatric patients with growth hormone deficiency [28]. It is not known, however, whether it also improves the osteopenia in MPS patients. In a GH deficient rat model it was demonstrated that $\mathrm{GH}$ administration increases periosteal and endocortical bone formation and mitigates trabecular bone loss by increasing bone formation [28]. Since trabecular bone loss has been demonstrated in most MPS animal models, it may be worthwhile to investigate the effect of $\mathrm{GH}$ dosing in MPS patients [12]

Physiotherapy and exercise might also improve osteopenia in MPS patients [12]. Physical exercise improves bone mass in growing children. Although the precise mechanism whereby it influences bone metabolism is not known, responses to greater mechanical stress and to changes in endocrine parameters are both likely contributors [29].

Therapeutic strategies that enhance bone formation may reduce the incidence of bone disease in MPS patients. Supplementation with calcium and vitamin D may be an inexpensive approach to mitigate osteopenia and improve quality of life in patients with advanced MPS, tailoring dosage to the individual patient, ensuring compliance, and carefully monitoring hypocalcemia/ hypercalciuria [11]. Subsequent studies are still required to establish whether rapid restoration of vitamin D body stores has an impact on disease course and outcome. The study of pathologies associated with MPS are conducted on relatively small groups of patients due to the 
fact that this is a very rare disease. This creates a need for further research, meta-analysis of the obtained results, and the exchange of experience between research centers working in this field.

\section{Conclusions}

MPS II patients have disturbed serum parameters of bone metabolism and may have increased risk of osteoporosis or osteomalacia.

Supplementation with vitamin D may be required in all MPS patients.

\section{Acknowledgements}

We gratefully acknowledge the study participants and their parents.

The authors declare no conflict of interest.

\section{References}

1. Neufeld EF, Muenzer J. The mucopolysaccharidoses. In: The metabolic and molecular basis of inherited disease. Scriver CR, Beaudet AL, Sly WS (eds.). McGraw-Hill, New York 2001; 3421-3452.

2. Nelson J, Crowhurst J, Carey B, Greed L. Incidence of the mucopolysaccharidoses in Western Australia. Am J Med Genet A 2003; 123A: 310-313.

3. Baehner F, Schmiedeskamp C, Krummenauer F, et al. Cumulative incidence rates of the mucopolysaccharidoses in Germany. J Inherit Metab Dis 2005; 28: 1011-1017.

4. Jurecka A, Krumina Z, Żuber Z, et al. Mucopolysaccharidosis type II in females and response to enzyme replacement therapy. Am J Med Genet A 2012; 158A: 450-454.

5. Scarpa M, Almássy Z, Beck M, Mucopolysaccharidosis type II: European recommendations for the diagnosis and multidisciplinary management of a rare disease. Orphanet J Rare Dis 2011; 6: 72 .

6. Simonaro CM, D'Angelo M, Haskins ME, Schuchman EH. Joint and bone disease in mucopolysaccharidoses $\mathrm{VI}$ and VII: identification of new therapeutic targets and biomarkers using animal models. Pediatr Res 2005; 57: 701-707.

7. Simonaro CM, D'Angelo M, He X, et al. Mechanism of glycosaminoglycan-mediated bone and joint disease: implications for the mucopolysaccharidoses and other connective tissue diseases. Am J Pathol 2008; 172: 112-122.

8. Chiaro JA, Baron MD, Del Alcazar CM, et al. Postnatal progression of bone disease in the cervical spines of mucopolysaccharidosis I dogs. Bone 2013; 55: 78-83.

9. Polgreen LE, Thomas W, Fung E, et al. Low bone mineral content and challenges in interpretation of dual-energy $\mathrm{X}$-ray $a b$ sorptiometry in children withmucopolysaccharidosis types I, II, and VI. J Clin Densitom 2014; 17: 200-206.

10. Fung EB, Johnson JA, Madden J, et al. Bone density assessment in patients with mucopolysaccharidosis: A preliminary report from patients with MPS II and VI. J Pediatr Rehabil Med 2010; 3: 13-23.

11. Rigante D, Caradonna P. Secondary skeletal involvement in Sanfilippo syndrome. QJM 2004; 97: 205-209.

12. Oussoren E, Brands MM, Ruijter GJ, et al. Bone, joint and tooth development in mucopolysaccharidoses: Relevance to therapeutic options. Biochim Biophys Acta 2011; 1812: 1542-1556.

13. Kachur E, Del Maestro R. Mucopolysaccharidoses and spinal cord compression: case report and review of the literature with implications of bone marrow transplantation. Neurosurgery 2000; 47: 223-228.

14. Weisstein JS, Delgado E, Steinbach LS, et al. Musculoskeletal manifestations of Hurler syndrome: long-term follow-up after bone marrow transplantation. J Pediatr Orthop 2004; 24: 97-101.

15. Sifuentes $M$, Doroshow R, Hoft R, et al. A follow-up study of MPS I patients treated with laronidase enzyme replacement therapy for 6 years. Mol Genet Metab 2007; 90: 171-180.

16. Jurecka A, Marucha J, Jurkiewicz E, et al. Enzyme replacement therapy in an attenuated case of mucopolysaccharidosis type I (Scheie syndrome): a 6.5-year detailed follow-up. Pediatr Neurol 2012; 47: 461-465.

17. Żuber Z, Różdżyńska-Świątkowska A, Jurecka A, Tylki-Szymańska $A$. The effect of recombinant human iduronate-2-sulfatase (Idursulfase) on growth in young patients with mucopolysaccharidosis type II. PLoS One 2014; 9: e85074.

18. Holick MF. Vitamin D deficiency. N Engl J Med 2007; 357: 266281.

19. Ross AC, Manson JE, Abrams SA, et al. The 2011 report on dietary reference intakes for calcium and vitamin $D$ from the Institute of Medicine: what clinicians need to know. J Clin Endocrinol Metab 2011; 96: 53-58.

20. Uziel Y, Zifman E, Hashkes PJ. Osteoporosis in children: pediatric and pediatric rheumatology perspective: a review. Pediatr Rheumatol Online J 2009; 7: 16.

21. Zemel BS, Leonard MB, Kelly A, et al. Height adjustment in assessing dual energy $\mathrm{X}$-ray absorptiometry measurements of bone mass and density in children. J Clin Endocrinol Metab 2010; 95: 1265-1273.

22. Green JJ, Robinson DA, Wilson GE, et al. Calcitriol modulation of cardiac contractile performance via protein kinase C. J Mol Cell Cardiol 2006; 41: 350-359.

23. Brehm JM1, Schuemann B, Fuhlbrigge AL, et al. Serum vitamin D levels and severe asthma exacerbations in the Childhood Asthma Management Program study. J Allergy Clin Immunol 2010; 126: 52-58.e5.

24. Jeng L, Yamshchikov AV, Judd SE, et al. Alterations in vitamin $D$ status and anti-microbial peptide levels in patients in the intensive care unit with sepsis. J Transl Med 2009; 7: 28.

25. Fromigué 0 , Marie PJ, Lomri A. Differential effects of transforming growth factor beta2, dexamethasone and 1,25-dihydroxyvitamin D on humanbone marrow stromal cells. Cytokine 1997; 9: 613-623.

26. Lin HY, Shih SC, Chuang CK, et al. Assessment of bone mineral density by dual energy $x$-ray absorptiometry in patients with mucopolysaccharidoses. Orphanet J Rare Dis 2013; 8: 71.

27. Peacock M. Osteomalacia and rickets. In: Metabolic bone and stone disease. Nordin B, Need A, Morris H (eds.). Livingstone, London 1993; 83-118. 
28. Guevarra MS, Yeh JK, Castro Magana M, Aloia JF. Synergistic effect of parathyroid hormone and growth hormone on trabecular and cortical bone formation in hypophysectomized rats. Horm Res Paediatr 2010; 73: 248-257.

29. Maïmoun L, Sultan C. Effects of physical activity on bone remodeling. Metabolism 2011; 60: 373-388. 